\title{
Selection of corn hybrids ensuring the production of high-energy feed for modern dairy farming
}

\author{
N.N. Zezin", M.A. Namyatov, M.Yu. Sevostyanov, and P.Yu. Ovchinnikov \\ FSBSI «Ural Federal Agrarian Research Center of the Ural Branch of the Russian Academy of \\ Sciences» 620142, Yekaterinburg, st. Belinsky, 112-a, Po Box 269, Russia
}

\begin{abstract}
The "line" of hybrids recommended by the Ural Research Institute of Agriculture Ob $140 \mathrm{SV}$ (FAO 140), Ross $130 \mathrm{MV}$ (FAO 130) and Kuban 101 SV (later Kuban 102 SV) (FAO 120) in 2016...2020 occupied $81.8 . .90 .6 \%$ in the structure of sown seeds in the Sverdlovsk region. The area under corn by 2014 increased to 19.39 thousand hectares (6.3 times compared to 2008) and in 2015...2020 it stabilized at the level of 19.3...21.0 thousand hectares. The production test of the "grain" corn cultivation technology developed by the Ural Research Institute of Agricultural Sciences was carried out in four basic farms, in which the area of corn sown increased by 1.9 times over the period from 2012 to 2020 , with a simultaneous increase in the sowings of high-protein crops: alfalfa and oilseeds. In the agricultural organizations of the SEC "Kilachevsky" and the SEC named after. The starch content in the silo reached 202-364 $\mathrm{g} / \mathrm{kg}$ in $2017 \ldots 2020$, in some years it decreased to $142 \ldots 146 \mathrm{~g} / \mathrm{kg}$ (SEC "Kilachevsky") and to $64 \ldots 67 \mathrm{~g} / \mathrm{kg}$ (SEC im. Zhukov). Over the past 3...5 years, individual farms of the region have begun to harvest cornage from corn. In the SEC "Kilachevsky", the starch content in the new type of feed was $247 \mathrm{~g} / \mathrm{kg} \mathrm{SV}$ in 2018, 341...407 g/kg in 2019 and $439 \mathrm{~g} / \mathrm{kg} \mathrm{SV}$ in 2020. The research was carried out on the basis of the FSBSI URFANITS UrB RAS as part of the State Task on the topic "Creation and improvement of adaptive technologies for the cultivation and processing of economically significant agricultural crops based on the optimization of biotic and abiotic factors".
\end{abstract}

\section{Introduction}

In the first years of corn introduction in the Urals, a number of scientists proved the feasibility of growing varieties and hybrids with a period of germination - wax ripeness of 95-100 days, which gave high yields of dry mass with ears of milk-wax ripeness $[1,2,3]$. N.N. Zezin, A.E. Panfilov, N.I. Kazakova et al. (2017) note that in the southern regions of Russia, it was not possible to develop seed production of early-maturing varieties and hybrids of corn adapted in the Urals. The seeds of late-maturing hybrids continued to be supplied in the Sverdlovsk Region, reaching the tasseling phase - ear flowering, by harvesting. As a result, the dry matter

*Corresponding author: nikitazezin@yandex.ru 
content in the green mass during the harvest period was very low $(10 \ldots 15 \%)$. To solve this problem, the task was set to select corn hybrids with FAO 120...150, which reach the phase of grain milk-wax ripeness by harvesting, providing a high starch content in the dry matter of silage and cornage.

\section{Materials and methods}

The research was carried out in field experiments at the Koltsovsky site of the Ural Research Institute in 2012...2020. The weather conditions were different: the hydrothermal coefficient of the period May...September was 1.24 in 2012, 0.81 in 2016, and reached 2.13 in 2015, with an average annual value of 1.57. Farm tests of the developed "grain" technology of corn cultivation were carried out in four basic farms of the Sverdlovsk region: SEC "Kilachevsky", SEC n.a. Zhukov, JSC "Agrofirma "Patrushi", LLC "Nekrasovo 1".

\section{Results and discussion}

Studies of many scientists have found that during the maturation of corn plants, the ratio of nutrients changes: the content of dry matter and starch increases to the full ripeness phase, but the content of sugar and raw protein decreases. According to D. Shpaar et al. (2009), by the time of flowering, the starch concentration in the dry matter reaches $2 \%$ and only by the end of the milk ripeness - beginning of the wax ripeness increases to $14 \ldots .22 \%$. In the experiments of the Ural Research Institute of Agriculture, the chemical analysis of plants showed that the main part of starch is contained in corn grain (Table 1).

Table 1. Starch content in various organs of corn plants, \% (2011...2013).

\begin{tabular}{|c|l|c|c|c|c|}
\hline No. & \multicolumn{1}{|c|}{ Hybrid } & FAO & Grain & Leaf & Stem \\
\hline 1 & Kubansky 101 SV & 120 & 75.2 & 4.20 & 4.36 \\
\hline 2 & Ross 130 MV & 130 & 74.4 & 3.44 & 4.19 \\
\hline 3 & Omka 130 & 130 & 74.0 & 3.02 & 4.21 \\
\hline 4 & Kubansky 141 MV & 140 & 73.2 & 2.50 & 3.06 \\
\hline 5 & Obsky 140 SV & 140 & 72.7 & 2.64 & 2.89 \\
\hline 6 & Mashuk 150 MV & 150 & 71.7 & 2.56 & 2.91 \\
\hline 7 & Omka 150 & 150 & 71.4 & 2.57 & 2.77 \\
\hline 8 & Katerina SV & 170 & 70.0 & 2.15 & 2.57 \\
\hline 9 & Mashuk 170 MV & 170 & 70.0 & 2.40 & 2.68 \\
\hline 10 & Ross 140 MV & 180 & 68.2 & 1.91 & 2.32 \\
\hline 11 & Klifton & 180 & 69.0 & 2.24 & 2.57 \\
\hline 12 & K 180 SV & 190 & 66.8 & 2.04 & 2.40 \\
\hline & On average & & 71.4 & 2.64 & 3.08 \\
\hline
\end{tabular}

In the grain of hybrids with the FAO index of 120...140 (Kubansky $101 \mathrm{SV}$, Ross 130 MV, Omka 130, Kubansky 141 MV, Obsky 140 SV), the starch content was the highest (72.7...75.2\%), and in Klifton hybrids (FAO 180) and K $180 \mathrm{SV}$, it was 69.0 and $66.8 \%$. On average, of the 12 hybrids studied, the starch content in the grain was $71.4 \%$, in the leaves $-2.64 \%$, in the stems $-3.08 \%$. In studies of 10 samples of $2018 \ldots 2019$, the starch content in dry grain ranged from 70.4 to $75.1 \%$ [6].

Thus, the feed qualities of corn are largely determined by the amount of dry matter and starch in the ears and their proportions in the dry matter of the whole plant. The higher the dry matter content in corn plants, the more energy is contained in the finished feed. 
Long-term research of the Ural Research Institute of Agriculture for the selection of hybrids adaptive to local conditions, working out the "grain" technology of their cultivation to obtain high-quality silage and cornage has shown that the productivity of corn depends mainly on the early ripeness of hybrids, the timing of sowing, the timing of harvesting and the weather conditions of the year. Thus, in 2010, with the sum of positive temperatures for May...September $2355^{\circ} \mathrm{C}$ (the average annual norm of $2042^{\circ} \mathrm{C}$ ) when sowing on May 16 and harvesting on September 16, the dry matter content in the green mass was $40.4 \%$ in the hybrids Obsky 140 SV, Kubansky 101 SV-41.8 \% when collecting dry matter, respectively, 15.1 and $10.5 \mathrm{t} / \mathrm{ha}$. The hybrid Obsky $140 \mathrm{SV}$ provided the largest starch harvest $(4.61 \mathrm{t} / \mathrm{ha})$ when sown on May 15, and the early-season hybrid Kubansky 101 SV - when sown on May $25(3.59 \mathrm{t} / \mathrm{ha})$.

In 2016 , when the sum of positive temperatures for May...September was $2420^{\circ} \mathrm{C}$, in the best variants, the collection of dry matter reached $16.8 \mathrm{t} / \mathrm{ha}$, and the yield of starch from 1 ha was $5.2 \mathrm{t}$.

In less favorable 2011 , the sum of positive temperatures for $\mathrm{V}$...IX was $2205^{\circ} \mathrm{C}$, dry matter content in green mass by mid-September (13.09) reached in hybrids: Katerina SV $23,3 \%$, Obsky $140 \mathrm{SV}-28,5 \%$, Kubansky $101 \mathrm{SV}-34,0 \%$, and by the end of August (30.08) equaled 19,$2 ; 23,0 ; 28.1 \%$. The starch content of the Kubansky $101 \mathrm{SV}$ hybrid was the highest and increased from harvesting on August 30 (12.4\%) to September 14 (28.7\%). The lowest indicators were found in the hybrid Katerina SV - 4.72 and $14.8 \%$.

The creation of the SE "Union of Seed Growers of the Urals" at the Ural Research Institute of Agriculture in 2008 contributed to the expansion of crops of early-season hybrids with FAO 120...140. The Ural Research Institute of Agriculture and SE "Union of Seed Growers of the Urals" jointly developed recommendations for the supply of corn seeds of adapted hybrids, based on annual environmental tests of hybrids, field experiments on improvement of "grain" technology of corn cultivation for silage and cornage. The farm test of the developed technology was carried out in different weather conditions in the basic farms (SEC "Kilachevsky", SEC n.a. Zhukov, CJSC "Agrofirma "Patrushi", LLC "Nekrasovo 1").

In $2011,95.4 \%$ of all corn seeds supplied to the region were the Katerina SV hybrid (FAO 170) and only 3.8\% - the Obsky 140 SV hybrid (FAO 140). By 2015, the share of seeds of the Katerina SV hybrid supplied to the Sverdlovsk region decreased to $26 \%$, and the Obsky $140 \mathrm{SV}$ hybrid increased to $70.5 \%$. In parallel, the study of individual elements of the technology of more early-season hybrids cultivation - Kubansky 101 SV (FAO 120) and Ross 130 MV (FAO 130) was carried out.

As a result of many years of research and farm testing of hybrids and techniques, a "line" of hybrids of various ripeness was determined, providing a conveyor supply of green mass with ears of milk-wax grain ripeness. For the early sowing period (May 10...15), the hybrid Obsky $140 \mathrm{SV}$ (FAO 140) is recommended, for the second term (May 15...20) Ross $130 \mathrm{MV}$ (FAO 130) and for the third sowing period (May 20...25) - Kubansky 101 SV. A distinctive feature of the Kubansky 101 SV hybrid was the low attachment of the ears during early sowing $(35 \ldots 45 \mathrm{~cm})$ and not a large height of the plants for harvesting $(165 \ldots 170 \mathrm{~cm})$, with later sowing these indicators increased to $50 \ldots 60 \mathrm{~cm}$ and $180 \ldots 210 \mathrm{~cm}$.

The analysis shows that in the structure of corn seeds sown in the Sverdlovsk region in 2016...2020, hybrids recommended by the Ural Research Institute of Agriculture with FAO $120 \ldots 140$ occupy the largest share - from 81.8 to $90.6 \%$ (Table 2). Over 5 years, the share of the Obsky $140 \mathrm{SV}$ hybrid has decreased by 2 times (from 52.5 to $25.5 \%$ ). At the same time, the volumes of sown hybrids with FAO $120 \ldots 130$ significantly increased: Ross 130 MV from 29 to $40.9 \%$, Kubansky 101 SV from 2.1 to $15.4 \%$. 
Table 2. The share of corn hybrids recommended by the Ural Research Institute of Agriculte in the total volume of sown corn seeds (according to the data of the FSBI "Rosselkhozcenter"), \%.

\begin{tabular}{|l|c|c|c|c|c|c|}
\hline \multirow{2}{*}{ Hybrid } & \multirow{2}{*}{ FAO } & \multicolumn{5}{|c|}{ Year } \\
\cline { 3 - 7 } & & 2016 & 2017 & 2018 & 2019 & 2020 \\
\hline Obsky 140 SV & 140 & 52.5 & 48.2 & 48.1 & 31.3 & 25.5 \\
\hline Ross 130 MV & 130 & 29.0 & 22.3 & 38.9 & 46.3 & 40.9 \\
\hline Kubansky 101 SV & 120 & 2.1 & 6.6 & 2.9 & 13.0 & 15.4 \\
\hline $\begin{array}{l}\text { Total for three } \\
\text { hybrids }\end{array}$ & & 83.6 & 77.1 & 89.9 & 90.6 & 81.8 \\
\hline $\begin{array}{l}\text { Total hybrids sown, } \\
\text { pcs. }\end{array}$ & & 15 & 11 & 12 & 9 & 15 \\
\hline
\end{tabular}

Thus, in a very short period in the feed production of the Sverdlovsk region, there was a radical change in the structure of forage crops. In 1950...1960, corn crops reached $150 \ldots 180$ thousand hectares, on average for 1971...1975, it occupied 117 thousand hectares, in 1986 94, 1987 - 88 thousand hectares. In subsequent years, the acreage of corn was rapidly declining and amounted to 5.69 thousand hectares in 2006, 3.36 in 2007; in $2008-3.09$ thousand hectares. With the supply of seeds of mainly early-season hybrids to the region with FAO $120 \ldots 150$, the area under corn by 2014 increased to 19.39 thousand hectares $(6.3$ times compared to 2008). In 2015...2020, the acreage of corn grown using "grain" technology stabilized at the level of $19.3 \ldots 21.0$ thousand hectares.

It is noteworthy that in recent years, along with corn, crops of high-protein crops alfalfa and oilseed crops (rapeseed, summer rape, flax) have become in demand and are increasing in the farms of the region (Table 3). All these crops, characterized by a high content of energy and protein, have a high drought resistance. The availability of such crops should also be expanded due to the fact that three years have been acutely arid over the past 10 years.

Table 3. Acreage of high-energy, high-protein crops in the Sverdlovsk region (according to the data of the Ministry of Agro-industrial Policy and Food of the Sverdlovsk region, 2011...2020), ha.

\begin{tabular}{|l|c|c|c|c|c|c|c|}
\hline \multirow{2}{*}{ Crop } & \multicolumn{7}{|c|}{ Year } \\
\cline { 2 - 9 } & 2011 & 2015 & 2016 & 2017 & 2018 & 2019 & 2020 \\
\hline Corn & 8.7 & 20.2 & 19.3 & 21.0 & 20.9 & 19.9 & 21.0 \\
\hline Alfalfa & 11.7 & 22.3 & 20.8 & 19.4 & 23.0 & 33.7 & 37.6 \\
\hline $\begin{array}{l}\text { Oilseed crops (rapeseed, summer } \\
\text { rape, flax) }\end{array}$ & 9.8 & 21.7 & 23.6 & 27.7 & 30.8 & 27.3 & 22.3 \\
\hline Total & 30.2 & 64.2 & 63.7 & 68.1 & 74.7 & 80.9 & 80.9 \\
\hline
\end{tabular}

The improvement of the structure of forage crops contributed to the rapid growth of dairy productivity. In 1987, for the first time, the Sverdlovsk region has become one of the 28 regions of the country that have achieved receipt of more than $3000 \mathrm{~kg}$ of milk from a cow per year. It took 20 years to increase milk productivity by 1 thousand $\mathrm{kg}$ from one cow (in 2006...2008, milk yield per cow ranged from 4119 to $4208 \mathrm{~kg}$ ). In 2010, milk production per 1 cow increased to $5160 \mathrm{~kg}$, in $2015-6381 \mathrm{~kg}$, in 2020 - to $7876 \mathrm{~kg}$.

Basic farms of SEC "Kilachevsky", LLC "Nekrasovo 1", CJSC "Agrofirma "Patrushi", SEC n.a. Zhukov, where the research was conducted, have the best herds of black-andwhite cattle in the Russian Federation in terms of milk productivity (Table 4). 
Table 4. Dynamics of milk yield per forage-fed cow in basic farms, $\mathrm{kg}$.

\begin{tabular}{|c|c|c|c|c|c|}
\hline Organization & 2012 & 2017 & 2018 & 2019 & 2020 \\
\hline SEC "Kilachevsky" & 8494 & 10787 & 11493 & 11963 & 12524 \\
\hline CJSC "Agrofirma "Patrushi" & 8885 & 9158 & 9299 & 9677 & 10646 \\
\hline SEC n.a. Zhukov & 6745 & 8604 & 8790 & 8914 & 10127 \\
\hline LLC "Nekrasovo 1" & 7385 & 10419 & 10570 & 10583 & 10835 \\
\hline
\end{tabular}

This is largely the result of a significant increase in the area of corn crops in these farms in recent years (Table 5). On average, for four agricultural enterprises, it increased from 375 hectares in 2012 to 700 hectares in 2020 , or by 1.9 times. At the same time, the ratio of corn crops and annual grasses was 1:1.7 in 2012, and by 2020 it was 1:1.

Table 5. The crop structure of the main fodder crops in farms with high milk productivity, 2012 and 2020 (according to the data of the Ministry of Agro-industrial Policy and Food of the Sverdlovsk region).

\begin{tabular}{|l|c|c|c|c|c|c|}
\hline \multirow{2}{*}{ Year } & \multicolumn{2}{|c|}{ Corn } & \multicolumn{2}{c|}{ Annual grasses } & \multicolumn{2}{c|}{ Perennial grasses } \\
\cline { 2 - 7 } & ha & $\%^{*}$ & ha & $\%^{*}$ & ha & $\%{ }^{*}$ \\
\hline \multicolumn{7}{|c|}{ SEC "Kilachevsky" } \\
\hline 2012 & 676 & 12.7 & 1109 & 20.9 & 3411 & 64.2 \\
\hline 2020 & 1204 & 17.6 & 1594 & 23.2 & 4061 & 59.2 \\
\hline \multicolumn{7}{|c|}{ LLC "Nekrasovo 1" } \\
\hline 2012 & 250 & 11.8 & 494 & 23.4 & 1252 & 59.2 \\
\hline 2020 & 607 & 16.2 & 623 & 16.6 & 2523 & 67.2 \\
\hline \multicolumn{7}{|c|}{ CJSC "Agrofirma "Patrushi" } \\
\hline 2012 & 450 & 13.6 & 962 & 29.2 & 1789 & 54.3 \\
\hline 2020 & 588 & 23.3 & 566 & 22.4 & 1373 & 54.3 \\
\hline \multicolumn{7}{|c|}{ SEC n.a. Zhukov } \\
\hline 2012 & 125 & 7.8 & 0 & 0 & 1470 & 92.2 \\
\hline 2020 & 399 & 20.1 & 166 & 8.4 & 1423 & 71.5 \\
\hline \multicolumn{7}{|c|}{ Average for four farms } \\
\hline 2012 & 375 & 12.5 & 641 & 21.4 & 1980 & 66.1 \\
\hline 2020 & 700 & 18.5 & 737 & 19.5 & 2345 & 62.0 \\
\hline
\end{tabular}

Note: * - the specific weight in the structure of the main forage crops (corn, annual and perennial grasses).

Considering the low protein value of corn mass, farms also increased the acreage of crops with a high protein content: alfalfa and oilseed crops. Moreover, the ratio of these crops in farms is different. For example, in 2020, 0.7 hectares of alfalfa and 1.5 hectares of oilseed crops (rapeseed) accounted for 1 ha of corn in the SEC "Kilachevsky", while 1.5 hectares of alfalfa and 0.45 hectares of rapeseed accounted for LLC "Nekrasovo 1". In the SEC n.a. Zhukov, the ratio of corn, alfalfa and rapeseed was equal to 1:1:0.75.

Thus, the expansion of sowings of corn hybrids with FAO 120...140, recommended by the Ural Research Institute of Agriculte, contributed to improving the quality of the feed base, increasing the milk productivity of the dairy herd. This is clearly seen in the example of basic farms, which in different weather conditions, along with harvesting high-quality silage, began to prepare a new type of feed - cornage with an even higher content of metabolic energy and starch.

In the SEC "Kilachevsky" in 2017, 2018 and 2020, the dry matter content in corn silage ranged from 258 to $364 \mathrm{~g} / \mathrm{kg}$ (Table 6). 
Table 6. The quality of corn silage from various hybrids in the SEC "Kilachevsky".

\begin{tabular}{|l|c|c|c|c|c|c|}
\hline \multirow{2}{*}{ Indicator } & $\begin{array}{c}\text { Meas. } \\
\text { unit }\end{array}$ & $\begin{array}{c}\text { Kubansky } \\
101 \mathrm{SV}\end{array}$ & $\begin{array}{c}\text { Obsky 140 } \\
\text { SV + Ross } \\
130 \mathrm{MV}\end{array}$ & $\begin{array}{c}\text { Obsky 140 } \\
\text { SV + Ross } \\
\text { 130 MV }\end{array}$ & $\begin{array}{c}\text { Obsky 140 } \\
\text { SV + Ross } \\
130 \mathrm{MV}\end{array}$ & $\begin{array}{c}\text { Obsky 140 } \\
\text { SV + Ross } \\
130 \mathrm{MV}\end{array}$ \\
\hline $\begin{array}{l}\text { Dry matter } \\
\text { (DM) }\end{array}$ & $\mathrm{g} / \mathrm{kg}$ & 364 & 258 & 272 & 267 & 339 \\
\hline $\begin{array}{l}\text { Metabolic } \\
\text { energy (ME) }\end{array}$ & $\begin{array}{c}\mathrm{MJ} / \mathrm{kg} \\
\mathrm{DM}\end{array}$ & 11.6 & 9.9 & 9.8 & 10.3 & 11.1 \\
\hline Crude protein & $\mathrm{g} / \mathrm{kg} \mathrm{DM}$ & 75 & 83 & 76 & 89 & 89 \\
\hline Raw fat & $\mathrm{g} / \mathrm{kg} \mathrm{DM}$ & 34 & 30 & 26 & 37 & 34 \\
\hline Raw fiber & $\mathrm{g} / \mathrm{kg} \mathrm{DM}$ & 156 & 259 & 260 & 231 & 189 \\
\hline Starch & $\mathrm{g} / \mathrm{kg} \mathrm{DM}$ & 382 & 142 & 146 & 193 & 286 \\
\hline
\end{tabular}

This indicator turned out to be the highest when laying a silo from the Kubansky 101 SV hybrid (FAO 120). There was also the highest starch content $-382 \mathrm{~g} / \mathrm{kg}$ of dry matter (DM). In other storages, the starch content was $142 \ldots 286 \mathrm{~g} / \mathrm{kg}$ DM. In storages No. 8 and No. 12 (2017), the low starch content $(142 \ldots 146 \mathrm{~g} / \mathrm{kg} \mathrm{DM})$ corresponded to lower indicators for exchange energy (9.8...9.9 MJ/kg DM versus $10.3 \ldots 11.6 \mathrm{MJ} / \mathrm{kg} \mathrm{DM}$ in other storages).

In the SEC n.a. Zhukov the highest content of dry matter in corn silage $(282 \ldots 344 \mathrm{~g} / \mathrm{kg})$ was noted in 2017, 2019, 2020 (table 7). In these variants, the starch content reached $202 \ldots$ $275 \mathrm{~g} / \mathrm{kg} \mathrm{DM}$.

Table 7. The quality of corn silage from various hybrids in the SEC n.a. Zhukov.

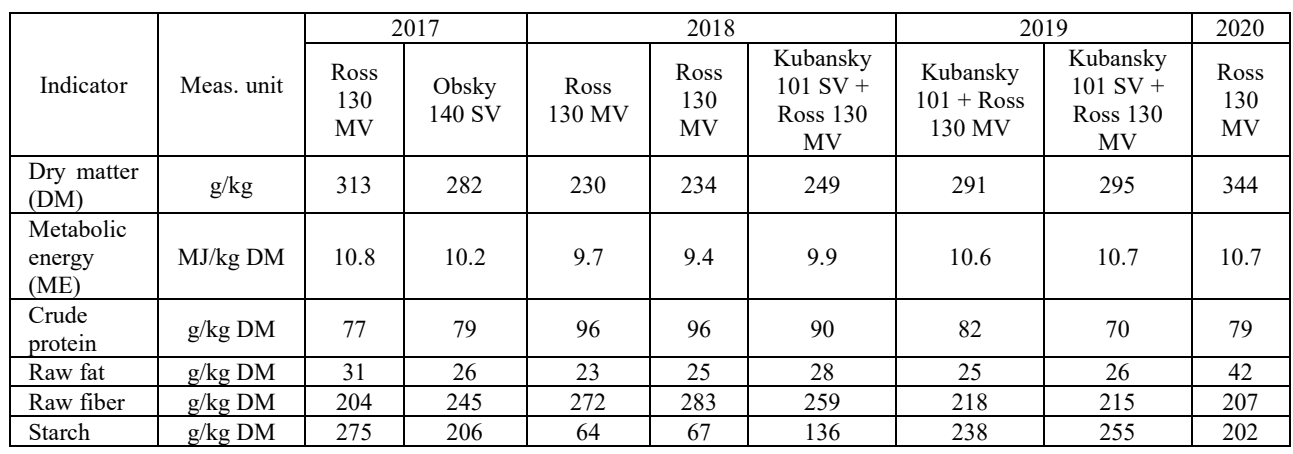

In 2018 , the dry matter content in the silo was less $(230 \ldots 249 \mathrm{~g} / \mathrm{kg})$ and the feed in these storages was characterized by a lower starch content $(64 \ldots 136 \mathrm{~g} / \mathrm{kg} \mathrm{DM})$.

Based on the data in Tables 6 and 7 , we can note a tendency to increase the concentration of raw fiber in the silo, reduce the indicators for raw fat and metabolic energy in variants with a lower starch content.

Over the past $3 \ldots 5$ years, individual agricultural enterprises have begun to harvest cornage from corn. In 2019, SEC "Kilachevsky" harvested cornage from the entire area of corn (hybrids were sown with FAO 120...140 Kubansky 101 SV, Ross 130 MV, Obsky 140 SV). The dry matter content ranged from 322 to $351 \mathrm{~g} / \mathrm{kg}$, starch in the dry matter - from 341 to $407 \mathrm{~g} / \mathrm{kg}$ (Table 8). In 2020, the dry matter content in the silo reached $431 \mathrm{~g} / \mathrm{kg}$ in the SEC "Kilachevsky", $490 \mathrm{~g} / \mathrm{kg}$ in the CJSC "Agrofirma "Patrushi", and the starch concentration was 439 and $512 \mathrm{~g} / \mathrm{kg} \mathrm{DM}$, respectively. 
Table 8. The quality of corn cornage in the farms of the Sverdlovsk region.

\begin{tabular}{|c|c|c|c|c|c|c|c|c|c|c|}
\hline \multirow[b]{3}{*}{ Indicator } & \multirow[b]{3}{*}{$\begin{array}{c}\text { Meas. } \\
\text { unit }\end{array}$} & \multicolumn{5}{|c|}{ SEC "Kilachevsky" } & \multicolumn{3}{|c|}{ SEC n.a. Zhukov } & \multirow{3}{*}{$\begin{array}{c}\text { JSC "A/f } \\
\text { "Patrushi" } \\
\text { Ross } 130 \\
\text { MV + } \\
\text { Obsky } 140 \\
\text { SV + } \\
\text { Mashuk } \\
140\end{array}$} \\
\hline & & 2018 & \multicolumn{3}{|c|}{2019} & 2020 & \multirow{2}{*}{$\begin{array}{c}\begin{array}{c}\text { Kuba } \\
\text { nsky }\end{array} \\
101 \\
\text { SV + } \\
\text { Ross } \\
130 \\
\text { MV }\end{array}$} & \multirow[b]{2}{*}{$\begin{array}{c}\text { Ross } \\
130 \\
\text { MV }\end{array}$} & \multirow[b]{2}{*}{$\begin{array}{c}\text { Kuba } \\
\text { nsky } \\
101 \\
\text { SV }\end{array}$} & \\
\hline & & $\begin{array}{l}\text { Obsky } \\
140 \mathrm{SV} \\
\text { + Ross } \\
130 \mathrm{MV}\end{array}$ & $\begin{array}{c}\text { Kuba } \\
\text { nsky } \\
101 \\
\text { SV }\end{array}$ & $\begin{array}{l}\text { Obsky } \\
140 \mathrm{SV}\end{array}$ & $\begin{array}{c}\text { Ross } \\
130 \\
\text { MV }\end{array}$ & $\begin{array}{l}\text { Obsky } \\
140 \mathrm{SV} \\
+ \text { Ross } \\
130 \mathrm{MV}\end{array}$ & & & & \\
\hline $\begin{array}{l}\text { Dry } \\
\text { matter }\end{array}$ & $\mathrm{g} / \mathrm{kg}$ & 294 & 341 & 322 & 351 & 431 & 403 & 397 & 378 & 490 \\
\hline $\begin{array}{l}\text { Metabolic } \\
\text { energy }\end{array}$ & $\begin{array}{c}\mathrm{MJ} / \mathrm{kg} \\
\mathrm{DM}\end{array}$ & 11.6 & 12.1 & 11.9 & 11.9 & 12.1 & 11.6 & 12.1 & 11.9 & 12.2 \\
\hline $\begin{array}{l}\text { Crude } \\
\text { protein }\end{array}$ & $\mathrm{g} / \mathrm{kg} \mathrm{DM}$ & 98 & 84 & 81 & 80 & 82 & 74 & 100 & 84 & 99 \\
\hline Raw fat & $\mathrm{g} / \mathrm{kg} \mathrm{DM}$ & 31 & 48 & 36 & 32 & 38 & 31 & 37 & 34 & 40 \\
\hline Raw fiber & $\mathrm{g} / \mathrm{kg} \mathrm{DM}$ & 199 & 180 & 178 & 144 & 134 & 160 & 133 & 184 & 95 \\
\hline Starch & $\mathrm{g} / \mathrm{kg} \mathrm{DM}$ & 247 & 341 & 343 & 407 & 439 & 382 & 397 & 310 & 512 \\
\hline
\end{tabular}

Thus, the experience of advanced farms in the Sverdlovsk region proves the possibility of preparing corn hybrids with FAO $120 \ldots 140$ and silage and cornage with a high concentration of metabolic energy, starch and fat in dry matter.

It should be emphasized that domestic breeders are actively working on creating hybrids for new areas of corn sowing - north and east of the southern traditional zone. Academician of the Russian Academy of Sciences V.S. Sotchenko, Yu.V. Sotchenko, N.A. Orlyansky et al. (2017) report that in recent years, the FSBSI All-Russian Research Institute of Maize has been paying special attention to the creation of hybrids with FAO 130...150. Results of variety testing of early-maturing hybrids in 2016 (Yu.V. Sotchenko, E.F. Sotchenko, E.A. Konareva, 2017) showed that in the group of hybrids (FAO 130), 5 hybrids were identified, more productive and taller in comparison with the Kubansky 101 SV standard. V.S. Sotchenko, A.E. Panfilov, A.G. Gorbacheva et al. (2021) indicate that for the northern zone of corn sowing, selection for a short growing season should be considered as a priority feature when creating adapted hybrids. According to American scientists [10], the development of drought-resistant corn hybrids is important in a changing climate.

Research on the ecological testing of early-maturing hybrids, started in 2008...2010, is continuing at the Ural Research Institute of Agriculture. In 2019 and 2020, the highest dry matter content in the green mass was observed in the hybrid Kubansky 102 SV 35.3 and $32.6 \%$. The share of ears in the dry matter reached 43.0 and $49.5 \%$, respectively. In 2019 , in a farm test on the fields of JSC "Agrofirma "Patrushi", the starch content in the ears was the highest in the hybrids Kubansky 102 SV 59.59\%, Ross 130 MV - 50.05\%. In 2019...2020, new hybrids K-140, Ross 125 and others were also studied in the basic farms.

\section{Conclusions}

The expansion of crops of corn hybrids with FAO 120...140, recommended by the Ural Research Institute of Agriculture, contributed to improving the quality of the feed base and, accordingly, increasing the milk productivity of the dairy herds of the Sverdlovsk region. The recommended "line" of corn hybrids, consisting of Kubansky 102 SV, Obsky 140 SV, and Ross $130 \mathrm{MV}$, continues to be improved on the basis of both field experiments and scientific and farm tests. 


\section{References}

1. P.I. Kuznetsov, Our research on the corn cultivation Maize in 1955, 4, 38-41 (Moscow, Kolos, 1956)

2. G.M. Sirotin, The results of work with corn in the Kurgan region in 1955-1957, 76-89 (Corn in the Urals. Sverdlovsk, 1958)

3. N.N. Manokina, Proceedings of the UralNIISKHoz. Sverdlovsk, IV, 199-204 (1962)

4. N.N. Zezin, A.E. Panfilov, N.I. Kazakova, M.A. Namyatov, I.N. Tsymbalenko, V.F. Gridin, E.S. Ivanova, R.D. Saltanova, Corn in the Urals, 204 (Yekaterinburg, 2017) https://elibrary.ru/item.asp?id=29856443

5. D. Shpaar et al. Corn (cultivation, harvesting, canning and use), 390 (Moscow: Publishing house of LLC "DUN Agrodelo", 2009)

6. M.R. Gonikova, V.I. Khoreva, V.G. Goldstein, L.P. Nosovskaya, L.V. Adikaeva, E.B. Khatefov, Works on applied botany, genetics and breeding 181(4), 56-64 (2020) DOI: 10.30901/227-8834-2020-4-56-64.

7. V.S. Sotchenko, Yu.V. Sotchenko, N.A. Orlyansky, etc., Maize and sorghum 4, 3-9 (2017)

8. Yu.V. Sotchenko, E.F. Sotchenko, E.A. Konareva, Corn and sorghum 4, 10-13 (2017)

9. V.S. Sotchenko, A.E. Panfilov, A.G. Gorbacheva, N.I. Kazakova, I.A. Vetoshkina, Agricultural Biology 56(1), 54-65 (2021)

10. Tineka R. Burkhead, Vincent P. Klink, AIMS Agriculture and Food Industry, 3(4), 406-425 (2018) 